\title{
Learning with Problem Solving Approach as Efforts to Improve the Ability of Mathematical Connection of Students in Accounting Study Programs in Bandung
}

\author{
Rachmat Hidayat*, Ignatius, Mirna Dianita, Niki Hadian \\ Widyatama University, Bandung, Indonesia \\ *Corresponding authorE-mail: rachmat.hidayat@widyatama.ac.id
}

\begin{abstract}
The mathematics learning outcomes of accounting study program students in Bandung are still low. For this reason, efforts are needed to improve the mathematics learning outcomes of accounting study students in Bandung. One of the efforts that was taken was by increasing the ability of students' mathematical connections. In order for students' mathematical connection capabilities to increase, an alternative learning is needed namely learning using a problem-solving approach. The population in this study were students of study program in Bandung, while the sample in this study was the first semester students at Widyatama University who were randomly selected according to class. The instrument used in this study is a mathematical connection ability test in the form of a description, and a Likert scale of student attitudes. From the results of the test of the mathematical connection ability test, it was found that the test had high reliability. The validity of the item is high, the distinguishing power is quite good, and the difficulty level is moderate. Based on the results of the analysis of research data, it is known that students who obtain learning with a problem-solving approach have better connection capabilities when compared to students who obtain conventional learning. In general, student responses are positive.
\end{abstract}

Keywords: Solving mathematical problems; mathematical connections.

\section{Introduction}

\subsection{Research Background}

The 2003 TIMSS (Trends in International Mathematics and Science Study) study reported that Indonesian students ranked 34th out of 45 countries included in the study [11] could be used as an indicator that strengthened the belief that Indonesian students learning outcomes in mathematics were low. Such ranking is certainly a lot of questioning and questioning even many individuals who are worried and concerned. Such rankings obtained by education people need to be responded positively, so that mathematics education in Indonesia becomes more advanced.

Further surveys of student learning outcomes in mathematics at several tertiary institutions in Tasikmalaya, Bandung, and Mataram (Flores) can be seen in Table 1 .

Table 1: Percentage of undergraduate and undergraduates in mathematics course in management study program

Table 1: Percentage of undergraduate and undergraduates in mathematics course in management study program
\begin{tabular}{|c|c|c|c|c|c|c|c|c|}
\hline No. & University & $2005 / 2006$ & $2004 / 2005$ & $2003 / 2004$ & $2002 / 2003$ & $2001 / 2002$ & Average \\
\hline 1 & University Siliwangi & 19 & 5 & 9 & 11 & 17 & 12.2 \\
\hline 2 & University Widyatama & 7 & 41 & 15 & 15 & 9 & 17.4 \\
\hline 3 & STIE Tridharma & 0 & 38 & 53 & 42 & 43 & 35.2 \\
\hline 4 & STIE Equity & 0 & 33 & 0 & 4 & 0 & 7.4 \\
\hline 5 & University Flores (Mataram) & 0 & 34 & 3 & 3 & 7 & 8 \\
\hline & Average & 5.2 & 30.2 & 16 & 15 & 13.8 & 13,91 \\
\hline
\end{tabular}

The average failure of the mathematics courses from the five universities above is $13.4634 \%$ (calculated using geometric averages). However, when viewed from the graduation level of the academic year 2001/2002 to 2005/2006, the results of student learning in universities that hold management and accounting study programs show an increasing trend because the average student failure rate per year decreases by $13.91 \%$ (calculated using geometric averages). This decline in average non-graduation indicates that we still have the opportunity to improve student learning outcomes.

The learning process that is dominated by lecturers with passive students is not recommended by the Committee on the Undergraduate Program in Mathematics (CUPM) [4]. According to [8], such learning processes are inadequate because of their low effec- tiveness and cannot develop a process of active participation in learning. In [4] recommends that learning mathematics in universities needs to: (1) involve activities that support all students, (2) present key ideas and concepts from various perspectives, (3) promote mathematical connections to other disciplines, (4) developing students 'ability to apply mathematics material to related disciplines, (5) introducing the latest mathematical topics and applications, (6) increasing students' perceptions of important mathematical roles. Referring to [5-6, 13], it seems that learning mathematics in the present era needs to emphasize more on: (1) the relationship between the material taught with everyday life situations, (2) solving real problems by trial and error, (3) thinking about how a formula or procedure is found, (4) ways or steps to 
solve problems (5) the role or usefulness of mathematics in the present life and found day.

As for universities, learning is defined as a programmed activity in facilitating, empowering and enabling (FEE) design, to make students learn actively, which emphasizes on learning resources. In addition, learning is also seen as a process of developing thinking creativity in order to: (1) improve thinking skills, (2) improve knowledge, and (3) construct new knowledge as an effort to improve mastery and development of lecture material [8], especially in the high teacher 's field of business (management and accounting), mathematics learning emphasizes more on the explanation and explanation of the important role of mathematics in understanding, exploring and developing accounting and management sciences. Mathematics played as it was quite reasonable for approaching a problem, simplify the presentation, understanding the problem, analyze problems, and make generalizations become more efficient and economical to use mathematics [16-17, 21].

Changing the learning model or approach is very likely to be carried out considering: first, the choice of learning approach or model is one of the authorities possessed by the lecturer, so that the lecturer can implement the model or approach he has chosen. Second, developed countries in the field of mathematics education have applied learning approaches that support problem solving skills, critical thinking skills and creative thinking abilities. Singapore for example, they have socialized the practice of creative problem solving learning (http://www.cdtl.nus.edu.sg). Third, according to [24] that each model guides us as we design instruction to help students achieve various objectives.

According to [3], the statement should be of particular concern to the people mathematics lecturer and developer of the concept of mathematics education to be able to overcome the low learning outcomes of mathematics. The low learning outcomes of mathematics are influenced by internal factors and external or environmental factors namely the model of presenting the material, the lecturer's personality, the learning atmosphere, lecturer competence, and the condition of the community. Lecturers as education providers have a significant share of the success of their students, in addition to other factors.

Therefore, various efforts need to be done by the lecturer so that student mathematics learning outcomes can increase. One of the efforts that can be done by the lecturer, so that students 'mathematics learning outcomes increase is by increasing students' understanding of mathematics itself. Because the low mathematics scores of students can be caused by students not understanding the mathematical concepts they have learned.

According to [18], making mathematical connections is a way to create an understanding of mathematics. Thus it can be concluded that by increasing the ability of students 'mathematical connections, students' understanding of mathematics will also increase. With a better understanding of mathematics, it is hoped that the learning outcomes of mathematics will also be better. Starting from this, one of the efforts suggested by researchers to be able to improve student mathematics learning outcomes is to improve the ability of students' mathematical connections. These efforts are in line with the Ministry of Education and Culture's statement [7] namely one of the objectives of teaching mathematics in schools is to prepare students to have mathematical skills that can be used in life in an ever-developing world and in everyday life. In [1] also argues that mathematics needs to be taught in school because it is always used in every aspect of life, and every subject requires appropriate mathematical skills.

The purpose of the mathematical connection is a link between topics in mathematics that are being studied with other topics in the mathematics course itself, linkages with other subjects, as well as linkages with everyday life. According to [12], the purpose of mathematical connections in schools is three, namely to broaden the horizons of students' knowledge, to view mathematics as a coherent whole, not as a material that stands alone and recognizes its relevance and the benefits of mathematics, both at school and in outside school. From this statement it can be concluded that mathematical connections are divided into three namely: (1) connections between mathematical topics, (2) connections with other disciplines, and (3) connections in daily life [8]. According to [18], it is expected that through mathematical connections students' thoughts and insights on mathematics will be more extensive, not only focused on one particular topic being studied. Then, it further stated that without the ability to do mathematical connections students must learn by remembering too many separate concepts.

In [3] suggests that in order to obtain good mathematical connection skills, a learning is needed that encourages active participation from students so that in the learning process there will be active communication between lecturers and students and between students themselves. In this case, students are given many opportunities to better understand a mathematical concept and its relationship to share ideas between students themselves. While lecturers can ask questions that can provoke students to think about solving a problem. Such learning can be carried out by applying problem solving approach.

According to [15], problem solving is an attempt to find a way out of a difficulty, achieving a goal that cannot be immediately achieved. Then, it further stated that in mathematics there are two kinds of problems namely problems to find and problems to prove. There are four problem solving steps in teaching mathematics according to [15]. These four steps are: (1) Understanding the problem. In this step, students are required to concoct existing data, unknown data, and the conditions needed to make decisions about the actions that should be taken. (2) Develop a plan for solving. In this step, students will find a connection between the data they have obtained and data that they have not yet known, (3) Implement the planned solutions. After all the data has been collected, then the students complete the problem step by step, (4) Test the completion obtained. The answers that have been obtained, reviewed the arguments and steps taken.

The more different types of problems faced by students and the greater their desire to think about the solutions, then the students will have greater opportunities to be able to deal with real life problems [20]. Students will also be better able to transfer their skills and knowledge to new situations. This is an indication that problem solving can foster student creativity. Creativity that arises in students includes the creativity of students to link one topic to another, relate it to other subjects, and can relate it to real life. In connection with this, problem-solving learning can be associated with efforts to improve students 'mathematical connections, so that students' understanding of mathematics also increases, and ultimately can improve mathematics learning outcomes.

\subsection{Identification of Problems}

From the background stated above, the problem can be broken down into the following two questions: (1) Is the mathematical connection ability of students who obtain learning with a problem solving approach better than the mathematical connection ability of students who obtain conventional learning (lectures)? (2) What is the attitude of students towards learning with a problem-solving approach in the aspect of mathematical connections?

\subsection{Research Purposes}

Based on the description in the background and formulation of the problem, there are two objectives of this study, namely: (1) Analyzing the ability of students to do mathematical connections between students who learn using a problem-solving approach with students who use lectures, (2) Analyze students' attitudes toward learning with problem solving approaches in the aspect of mathematical connections.

\subsection{Benefits of Research}

At least three benefits expected from this study, namely: (1) Help out develop students' ability to connect mathematics,

(2) Produce positive attitude of students to question the connection of mathematics, thus further encourage students to be more motivated to learn mathematics, (3) Increase the knowledge of lectur- 
ers on alternative mathematics learning that is possible to be applied as an effort to improve the ability of mathematical connections.

\section{Literature Review}

\subsection{Problem Solving Approach}

In [16] argues that problem solving is the highest type of learning because it is more complex than the previous type of learning. Gagne's type of learning is a type of gesture learning, stimulus response, sequence of motion, verbal sequence, differentiation, concept formation, rule formation and problem solving. In [16] argues that there are five steps that must be done in the problem solving process namely (1) presenting the problem in a clearer form, (2) stating the problem in a more operational form, (3) preparing alternative hypotheses and procedures expected work is good, (4) testing hypotheses and doing work to get results, and (5) retesting the results that have been obtained. So, the emphasis on learning with a problem solving approach is on what must be solved and how to solve the problem systematically and logically. There are several positive traits that want to be developed in mathematics learning with a problem solving approach which is expected students will have attitudes and habits of logical thinking, critical and systematic. To be able to achieve this goal, the participation of lecturers is needed. There are four instructions given by [14] to mathematics lecturers to foster students' problem solving behavior namely: (1) ensuring that students understand the problem, (2) helping students gather a frame of mind to help in creating plans, (3) creating a climate that is conducive to centralizing creative abilities to solve problems, (4) encouraging them to reflect on problems and ways to resolve them after students find the solution. In [14] suggested several abilities that are the goal in problem solving learning namely: (1) Problem solving is a form of education to be able to think systematically. In this case, during the process, the problem solving that is obtained must be communicated to others. Communication can be understood by others if the presentation is done systematically, both in terms of reasoning and language terms, (2) Problem solving is a teaching and learning activity that is meaningful (meaningful), to improve the nature of intellectual curiosity. If the problem faced to students is right, then it can stimulate their interest and creativity, (3) Problem solving allows students to develop into more analytical decisions in life. This is due to trained students in the skills to collect relevant information, organize basic concepts and principles that they have had, analyze information, and realize the need to re-examine the results they have obtained, (4) New knowledge can be found through problem solving (5) By solving problems, students apply the concepts and principles of mathematics to new situations. To solve problems, students must master the things that have been learned before and then use them in new situations. Its application can be in mathematics itself, maybe even in subjects or other fields, (6) Students play an active role in teaching and learning activities.

Problem solving as the highest type of learning, according to [9] has several benefits because mathematics learning with a problem solving approach will make students become more skilled at selecting relevant information, analyzing it, and examining the results; will bring intellectual satisfaction to students; will enhance students' intellectual abilities; and students will learn how to make discoveries. In [2] also holds the same opinion that problem solving obtained in the teaching of mathematics can be transferred to be used in solving other problems.

One of the factors that can support learning through problem solving approaches is students' interest or interest in the problem at hand. According to [25], there are three things that must be considered, so that students are interested in the problems they are facing, namely: providing an active, active and continuous experience in solving various problems; creating a positive relationship between student interest and success; and creating a close relation- ship between students, problems, problem solving behavior, and class atmosphere.

Limitations problem-solving learning by [10] is as follows: (1) If the questions given do not provide motivation for students to learn, students will feel the problem is just a waste of work, (2) If a student not interested and students are sure to be able to solve problems, students will be reluctant to try, (3) Effective problem solving requires a lot of preparation. The right problem must be formulated before developing because each question must be arranged in a way that produces specific student learning outcomes, (4) If students do not understand the reasons why students must try to solve problems, students will

not learn what should be learned, (5) Because students must be independent and not dependent on lecturers, students may not be able to solve all the things that should be solved, (6) smart students will dominate students who are weak in group work, (7) If the lecturer does not supervise students carefully then using inappropriate thinking strategies will result in inaccurate conclusions too. (8) Students who are familiar with the information obtained from lecturers and lecturers are the main resource persons and they will feel uncomfortable, (9) There are several students who have different learning styles with the use of learning with a problem solving approach.

\subsection{Conventional Learning}

According to [21], conventional learning (lectures) give the emphasis to new information by the lecturer so that teaching and learning activities are more focused on the lecturer. In this case class behavior and knowledge dissemination are controlled and determined by the lecturer. The essence of teaching using lectures according to [21] is to deliver knowledge to students. In this case, students are seen as objects that only accept what is given by the lecturer.

Lectures have weaknesses and strengths. In the opinion of some people who disagree with lecture learning [16], learning by using the lecture method will cause learning to only memorize which does not lead to understanding of students; cause students to be passive; students only actively record; whether or not the material to be taught is only based on lecturers' consideration; and the material that has been studied is quickly forgotten because it is only memorized.

The reason for some people who agree with lecture learning [16] is as follows: (1) Not all students can learn through reading, (2) There is a repetition from the lecturer in other words, while in the textbook no, (3) It can form complex problems, especially regarding new problems, while textbooks do not, (4) Can be used to summarize the many problems contained in various sources, (5) can be used if according to students the material presented is new, while the written material does not yet exist or is still small , (6) can provide opportunities at any time to the lecturer to summarize, criticize, or comment on the opinions of others , (7) can present material to be interesting, generate interest and pleasure to students rather than written material , (8) making teaching more planned, orderly, well prepared than the formulation of student discussion results, (9) relatively cheaper because it can load more students in one class per lecturer, (10) more flexible in terms of time, place, students, equipment, and student activities , (11) can walk without regard to the number of students, (12 ) can improve reinforcement for students, (13) lecturers can be used to see whether students participate actively in understanding the problem or not, when compared to the way of learning themselves.

\subsection{Understanding Mathematical Connections}

In [22] suggested several propositions from observations at school This argument is the formulation of the argument, the notation theorem, the contrast and diversity theorem, and the argument of association. In the association argument, it is stated that in mathematics between one concept and another concept there is a close 
relationship, not only in terms of content but from the formulas used as well.

According to [16], every concept in mathematics is related to other concepts. Furthermore, in [17] stated that there were no concepts or operations that were not related to other concepts or operations in a system. It states that mathematical connections require students to be able to understand the existence of internal and external relations of mathematics. Internal relations of mathematics include the relationship between topics in mathematics itself, while external relations include the relationship between mathematics and other subjects and relations with everyday life.

\subsection{Relevant Research}

Several studies on the ability of students to do mathematical connections have been carried out by $[18,23]$ report from the results of their research that high-achieving students have higher connection knowledge than students with low achievement. Likewise, in [18] reported that the ability of students' mathematical connections was still relatively low but the attitude of students towards the activities of mathematical connections showed a positive direction. While, in [23] reported that the ability of students' mathematical connections after learning with an open-ended approach has increased from the low category to the sufficient category. In general, students have a positive attitude towards learning with open-ended approaches and math connection problems.

\subsection{Research Hypothesis}

The hypothesis of this study consists of two parts namely: (1) the ability of the mathematical connection of students who obtain learning with a problem-solving approach is better than the mathematical connection ability of students who obtain learning by using lectures, and (2) the attitude of students towards mathematics learners with the problem solving approach to improve the ability of mathematical connections is positive.

\subsection{Operational Definition}

Operational definitions of the variables in this study are as follows: (1) Ability: potential, power, ability to do a job, (2) Mathematical connection: the relationship between topics discussed with other topics. The link here can be between topics in mathematics, the relationship of mathematics with other subjects, or the relationship with everyday life, (3) the ability of mathematical connections: the ability of students to solve problems related to mathematical connections, (4) problem solving approach: an approach in teaching that encourages students to find and solve existing problems. In this case, the problem solving method prioritizes the process rather than the results, (5) Lectures: teaching that emphasizes new information delivered by the lecturer to students. In this case, students are seen as objects that receive whatever is given by the lecturer.

\section{Methodology}

\subsection{Research Design}

This research was conducted using an experimental approach with the pretest-posttest control group design form. This design is used because this study uses a control group, there are two different treatments, and random sampling. The research design chart is as follows:

$\begin{array}{llll}\text { A: } & \text { O } & X & \text { O } \\ \text { A: } & \text { O } & & \text { O }\end{array}$

A: random sampling, $\mathrm{O}$ : initial test and final test, which is a test of the student's ability to make mathematical connections, $\mathrm{X}$ : learning with a problem solving approach in the experimental class.

\subsection{Population and Research Sample}

Considering the subject matter of mathematics is difficult to understand by students, the researcher chooses the subject of the population of private university students in Bandung. In addition, private university students have many prerequisite knowledges for the subject of mathematics in college. In this study, researchers want to observe intermediate ability students.

Based on data published by Kopertis Wilayah IV, Widyatama University includes a private university that is accredited A in Bandung. Because Widyatama University represents intermediate ability students, the research samples taken by researchers are first semester students. The selection of first semester students is because the mathematics that will be tested by researchers is studied in semester I. From all the first semester students, two classes are taken randomly to be made research sample. This technique is used because each class of all subjects has the same opportunity to be chosen as a sample. Then, from the two classes specify randomly, one class is defined as the control class and one class is set as the experimental class.

\subsection{Research Instruments}

The data in this study were obtained by using two kinds of research instruments namely the mathematical connection test in the form of a description, and the attitude scale with a Likert scale model. Descriptive tests are used to measure students' ability to make mathematical connections. The test given is in the form of a description because the researcher wants to see the student's thought process, as expected in problem solving learning. The attitude scale with the Likert scale model is used to determine students' attitudes toward learning with problem solving approaches in the aspect of mathematical connections.

\subsubsection{Mathematical Connection Ability Test Instrument}

Many test questions in this study are six description questions. Before making a test question, the test questions are made first. Then the test questions that have been made are analyzed to find out the validity of the contents. Before the test is given to the research subject, a trial is first carried out in the first semester of another class at Widyatama University which has studied the same material.

The score of the mathematical connection ability for the complete answer is 3 , the score for answering only part of it is 2 , the score for just answering is 1 , and the score for not answering is 0 . After the instrument is tested, then the results are analyzed. Analysis was emphasized on reliability, validity, differentiation, and level of difficulty. Based on the calculation results, the validity of the mathematical connection instrument for questions number 1,4 , and 6 is very high, and for numbers 2, 3, and 5 is high. As for the distinguishing power for questions number 1 and 4 , both numbers 2 , 3,5 , and 6 are sufficient. Differentiation shows the ability of the question to distinguish between smart students and less intelligent students. While, the level of difficulty about communication skills is difficult while others are. The level of difficulty for questions in the form of a description, according to [19] is divided into three groups namely: it is difficult if the right answer is only $27 \%$, while if the correct answer is $28 \%-72 \%$, and it is easy if the right answer is more from $72 \%$.

\subsubsection{Studen9t Attitude Scale}

The attitude scale aims to determine the student's attitude towards learning with a problem solving approach in the aspect of mathematical connections. The scale model used is a Likert scale model. The degree of assessment of a statement is divided into 5 categories, namely: strongly agree (SS), agree $(\mathrm{S})$, neutral $(\mathrm{N})$, disagree (TS), and strongly disagree (STS). In analyzing the results of the attitude scale, the qualitative scale is transferred to a quantitative scale. The granting of value is distinguished between negative statements and positive statements. For positive statements, giving 
the score is $\mathrm{SS}$ given a score of $5, \mathrm{~S}$ is given a score of $4, \mathrm{~N}$ is given a score of 3 , TS is given a score of 2 , and the STS is given a score of 1 . While for the negative statement, the score is SS given a score of $1, \mathrm{~S}$ is given score $2, \mathrm{~N}$ is given a score of $3, \mathrm{TS}$ is given a score of 4 , and STS is given a score of 5 .

To find out the attitude of students which has a positive or negative attitude, the average score of each student is compared to a neutral score. If the average score of a student is smaller than the neutral score, it means students have a negative attitude. Whereas if the average score of a student is greater than a neutral score, it means that students have a positive attitude.

\subsection{Data Collection Procedure}

Data collection techniques in this study were as follows: (1) The initial test was given to the experimental class and control class, (2) The implementation of learning. In the experimental group was given learning problem-solving approach, while the control class with lectures, (3) Provision of the final test connections mathematics experimental class and control class, followed by charging a scale of attitude in the experimental class, (4) Data analysis by ANOVA (Covariance Analysis) to accept or reject the proposed hypothesis. The calculation uses SPSS version 22 software, (5) Analyzing the results of the student attitude scale to determine the students 'attitudes toward learning by using problem solving methods as an effort to improve the ability of students' mathematical connections.

\subsection{Data analysis}

The data obtained in this study were subsequently analyzed by Mechanical ANCOVA using software SPSS version 22. The data analysis is emphasized on descriptive analysis, homogeneity of data communication capabilities of the two groups of college mathematics, influence lectures with problem-solving approach to mathematics communication ability, and see a linear relationship between beginning with final abilities in mathematical communication. There are student attitudes toward lectures with problem solving approaches to improve mathematical communication skills analyzed descriptively.

\section{Results and Discussion}

\subsection{Research Result}

The data obtained in this study is the data of students' mathematical connection ability tests and student Likert scale data. The results of the study are presented as follows.

\subsubsection{Descriptive Analysis}

The print out of ANOVA for descriptive analysis is presented in Table 2 .

Table 2: Descriptive statistics

\begin{tabular}{|c|c|c|c|}
\hline Lecture Type & Mean & Std. Deviation & $\mathrm{N}$ \\
\hline Lectures with a Problem- Solving Ap- & 8,179 & 2.1135 & 39 \\
proach Conventional Lectures & 5,789 & 2.0422 & 38 \\
Total & 7,000 & 2.3897 & 77 \\
\hline
\end{tabular}

Dependent variable: Post value

From the Descriptive Statistics table, it appears that the mean of the mathematical connection ability that is learning with a problem solving approach is 8,179 . While, the mean ability of conventional learning mathematics connections is 5,789. This means that the mean value of a mathematical connection ability that is learning with a problem-solving approach is much better than conventional students.

\subsubsection{Homogeneity of Mathematical Communication Ability} Data from the Two Classes

The homogeneity of mathematical communication ability data from the two study groups can be examined by the Levene's test. Levenes test results with SPSS 22 are shown in Table 3.

Table 3: Levene's test of equality of error variances

\begin{tabular}{|c|c|c|c|}
\hline $\mathrm{F}$ & $\mathrm{df} 1$ & $\mathrm{df} 2$ & Sig. \\
\hline .217 & 1 & 75 & .643 \\
\hline \multicolumn{4}{|c|}{ Dependent variable: Mathematical Communication Ability } \\
\hline
\end{tabular}

Test the null hypothesis that the error variance of the dependent variable is equal across groups.

Design: Intercept + Early Establishment + Lecture

From the Levene's Test of Equality of Error Variances table, it appears that Sig. $=0,643$ is greater than 0.05 , so statistically means the variance of the two lecture groups is homogeneous.

\subsubsection{The Influence of Lectures with a Problem-Solving Ap- proach to Mathematical Communication Ability}

The influence of lectures with problem solving approach to mathematical communication skills can be seen in print out ANOVA in the Tests of Between-Subjects Effects section in Table 4.

Table 4: Tests of between-subjects effects

\begin{tabular}{|c|c|c|c|c|c|}
\hline Source & $\begin{array}{c}\text { Type III Sum of } \\
\text { Squares }\end{array}$ & df & Mean Square & F & Sig. \\
\hline Corrected Model & $114,839^{\mathrm{a}}$ & 2 & 57,419 & 13,313 & .000 \\
\hline Intercept & 651,727 & 1 & 651,727 & 151.108 & .000 \\
\hline Initial ability & 4,898 & 1 & 4,898 & 1,136 & .290 \\
\hline Lecture & 112,765 & 1 & 112,765 & 26,145 & .000 \\
\hline Error & 319,161 & 74 & 4,313 & & \\
\hline Total & 4207,000 & 77 & & & \\
\hline Corrected Total & 434,000 & 76 & & & \\
\hline
\end{tabular}

Dependent variable: Mathematical Communication Ability

$\mathrm{R}$ Squared $=.265$ (Adjusted R Squared $=.245$ )

In the Tests of Between-Subjects Effects table, it appears that Sig. Initial ability of 0.290 is greater than 0.05 , this means that the initial ability does not affect the success of students in mathematical communication. The lectures namely lectures with problem solving approaches and lectures conventionally give different effects on mathematical communication skills because the value of Sig. lecture of 0,000 which is much smaller than 0.05 . In other words, learning outcomes with problem-solving approaches differ from learning outcomes with conventional approaches.

4.1.4. Relationship Linear Initial Competence with Final Ability in Mathematical Communication

To see the linear relationship of initial ability and final ability in mathematical communication can be seen from Lack of Fit Tests. The print out of ANOVA on the Lack of Fit Test is shown in Table 5 .

Table 5: Dependent variable: Mathematical Communication Ability

\begin{tabular}{|c|c|c|c|c|c|}
\hline & Sum of Squares & Df & Mean Square & F & Sig. \\
\hline Lack of Fit & 39,541 & 10 & 3,954 & .905 & .534 \\
Pure Error & 279,620 & 64 & 4,369 & & \\
\hline
\end{tabular}

From the Lack of Fit table, the above test shows that the Sig. $=0$, 534. Because of sig. $=0,534$ is greater than 0.05 , it can be concluded that there is a linear relationship between initial ability and final ability in mathematical communication.

\subsubsection{Student Attitudes}

Filling the student attitude scale is done in class with a problem solving approach after the final test on the class. This student atti- 
tude scale analysis is done by finding the average score of each answer given by students and searching for the average score of each student statement item. The average score of each answer given by the student and the average score of each item statement is then compared with a neutral score that is 3 . If the average student score is smaller than the neutral score, it means that students have a negative attitude. And vice versa, if the average score given by students is greater than the neutral score, meaning students have a positive attitude. Likewise, for the average score of each item statement, if the average score of the item statement is smaller than the neutral score, meaning that students have a negative attitude towards the statement. Whereas, if the average score of the statement item is greater than the neutral score, it means that the student has a positive attitude towards the statement.

The attitude to be observed in this study is the attitude of students towards learning with a problem-solving approach in the aspect of mathematical connections. The attitude observed was divided into three groups, namely attitudes towards mathematics learning, attitudes toward learning with problem solving approaches, and attitudes towards mathematical connections.

\subsubsection{Student Attitudes towards Mathematics Learning}

Students' attitudes towards mathematics learning were analyzed from their answers to the following 5 statements:

1. I was happy with mathematics lessons, 2. If I was given the choice between attending and leaving mathematics then I would choose to leave it, 3. I tried to be serious in taking lessons mathematics, 4. In mathematics learning, I prefer lecturers to explain and students listen, and 5. The benefits of learning mathematics are less I can feel.

The results of an analysis of students 'attitudes to mathematics learning show that students' preference for mathematics is quite good. This can be seen from the positive response given by students to the number 1 statement. The motivation of students towards mathematics learning is also good. This can be seen from the positive response given by students to statements number 2, 3, and 5. Students can feel the benefits of learning mathematics so they try to be serious in taking mathematics lessons. Even if they are given a choice between participating in mathematics or leaving mathematics, they generally argue to keep on studying mathematics.

\subsubsection{Students' Attitudes towards Learning with a Problem- Solving Approach}

The attitude of students towards learning with problem solving approaches was analyzed from their answers to the following 5 statements: 1. I am not happy with the way to teach mathematics lecturers, 2. Learning mathematics with a problem solving approach is confusing and boring, 3 . The problem of mathematical connections is boring, 4. With problem solving learning, students are trained to solve problems in a planned manner, and 5. I am happy when learning mathematics using a problem solving approach.

The results of the analysis of students 'attitudes toward learning with problem solving approaches indicate that students' preference for learning with problem solving approaches is quite good. This can be seen from the average score of the four statements namely statements number 1,2,3, and 5 are 3.4615. This means that in general the response given by students in terms of students' preference for learning with a problem solving approach is positive. Even though, students give a negative response to statement number 4 This means that students like learning with a problem solving approach. The negative response given by students in statement number 2, because students are not familiar with this approach.

Student activities in solving math connection problems are also quite good. This can be seen from the positive response given by students to statement number 4 . Students argue that learning with a problem-solving approach will train them to solve problems planned.

\subsubsection{Students' Attitudes towards Mathematical Connec- tions}

Students' attitudes towards mathematical connections were analyzed from their answers to the following 10 statements: 1 . Whenever there is a math problem, I always think about its relation to other lessons, 2. When faced with difficult mathematical connections, I consider it a challenge, 3 . How the teaching lecturer made me like this subject, 4 . The question about mathematical connections only inhibits learning activities, 5. Mathematics cannot be applied in everyday life, 6. I always try to avoid difficult math connection problems, 7. I interested in developing the ability of mathematical connections by learning more, 8 . I do not feel any mutual support between the material contained in mathematics and the material contained in other subjects, especially economics and accounting, 9. There is no slight interest for me to learn how to solve math connection problems, and 10. Matter of mathematical connections is boring.

The results of an analysis of students 'attitudes towards mathematical connections shows that students' preference for the matter of mathematical connections is quite good. This can be seen from the positive response given by students to the statements number 4,7 , and 10. Students' interest in solving math connection problems is also quite good. This can be seen from the positive response given by students to the statements number $2,3,6$, and 9 . Students feel the need to be given questions about mathematical connections in each lesson. They feel they have a challenge when they encounter a difficult mathematical connection.

In general, students respond positively to the relation of mathematics to other lessons and to everyday life, even though students give a negative response to number 1 . In general, students argue that mathematics can be applied in everyday life, and the material in mathematics can support other lessons. Based on data on student attitude scale, students generally responded positively. This can be seen from the average score given by each student. Of the 39 students who were the respondents of the study, 37 students responded positively and only 2 gave negative responses. That is judging from the average score of students it turns out that students give a positive response to efforts to improve the ability of students' mathematical connections with learning using a problem solving approach.

\subsection{Discussion}

\subsubsection{Learning with the Problem Solving approach and the ability of Student Mathematical Connections}

Based on the results of data analysis, problem-solving approach has a good potential to improve the ability of mathematical connections amongst students. This can be seen from the results of the analysis of the difference between the two average final test scores between the experimental class whose lectures used a problemsolving approach and the control class which was conventionally studied, there were differences. In this case, the experimental class provides better results compared to the control class.

Based on the analysis of the answers given by students, it appears that students actually have the ability to understand the problem well enough, only to understand the problem students need a relatively long time. Because the time needed by students to be able to understand the problem for a long time, then it will result in the unresolved of all questions in accordance with a predetermined time allocation.

From the answers given by students, it is seen that what is most confusing to students is a matter related to other subjects. This is possible because of the weak understanding of students towards the subjects concerned or the weak ability of student connections. 
Students generally feel happy with the problems of mathematical connections because they are close to their areas of expertise and life. However, they also feel that they have a lot of difficulties in understanding mathematics connections. That is because they are not familiar with such problems.

\subsubsection{Students' Attitude}

Based on the analysis of the attitude scale content data, it turns out that the average student attitude score is 3.6527 , meaning that students generally have a positive attitude towards learning with a problem solving approach as an effort to improve the ability of students' mathematical connections. This can also be seen from the 39 students who were the respondents of the study, it turned out that students who gave a positive response were 37 students $(94.8718 \%)$ and who gave negative responses as much as 2 students $(5.1282 \%)$.

For an analysis of each statement item on the attitude scale, it turns out that from 20 statements. There were two statements that responded negatively and the remaining 18 statements responded positively. Two statements that responded negatively by students that statement se each have a math problem, I always think about the relation with other subjects and learning math problem- solving approach is too confusing and boring. The average score for the two statements is 2.8974 and 2.9231 . The student's negative response was given in the second the statement is possible because students are not familiar with learning using problem solving approaches and math connection problems.

\section{Conclusion}

Capacity of connection mathematics students who receive learning with problem solving approach is better than the ability to connect math students who receive learning with lecture. The attitude of students towards mathematics learners with problem solving approaches to improve the ability of mathematical connections is positive.

\section{References}

[1] Abdurrahman, M. (1999). Pendidikan bagi Siswa Berkesulitan Belajar. Rineka Cipta.

[2] Bell, F.H. (1978). Teaching and Learning Mathematics in Secondary School. Win C. Brown Company Publisher.

[3] Carilah. (2005). Pembelajaran dengan Pendekatan Pemecahan Masalah Sebagai Upaya Meningkatkan Kemampuan Koneks Matematika Siswa SMA di Bandung. Tesis, Universitas Pendidikan Indonesia.

[4] CUPM. (2004). Undergraduate Programe and Courses in the Mathematics Science: CUPM Curriculum Guide 2004. USA: The Mathematical Association of America.

[5] Departemen Pendidikan Nasional. (2003). Kurikulum 2004: Standar Kompetensi Mata Pelajaran Matematika Sekolah Menegah Pertama dan Madrasah Tsanawiyah. Pusat Kurikulum, Badan penelitian dan Pengembangan Departemen Pendidikan Nasional.

[6] Departemen Pendidikan Nasional. (2003). Kurikulum 2004 Standar Kompetensi Mata Pelajaran Matematika Sekolah Menegah Atas dan Madrasah Aliyah. Pusat Kurikulum, Badan penelitian dan Pengembangan Departemen Pendidikan Nasional.

[7] Depdikbud. (1993). Kurikulum Sekolah Menengah Umum. GBPP Mata Pelajaran Matematika. Depdikbud.

[8] Direktorat Pembinaan Akademik dan Kemahasiswaan. (2005). Tanya Jawab Seputar Kurikulum Berbasis Kompetensi di Perguruan Tinggi. Depdiknas.

[9] Hudoyo, H. (1979). Pengembangan Kurikulum Matematika dan Pelaksanaannya di Depan Kelas. Usaha Nasional.

[10] Killen, R. (1998). Effective Teaching Strategies Lessons from Research and Practice. Social Science Press.

[11] Media Indonesia. (2004). Penguasaan Matematika dan Sains Masih Rendah.

[12] National Council of Teachers of Mathematics (NCTM). (1989). Curriculum and Evaluation Standards for School Mathematics. Authur.
[13] NCTM. (2000). Principal and Standards for School Mathematics. NCTM.

[14] Polya, G. (1973). Competensy Based Educations. Prentice Hall.

[15] Polya, G. (1985). How to Solve It. A New Aspect of Mathematical Method.Princeton University Press.

[16] Ruseffendi, E.T. (1991). Pengantar kepada Membantu Guru Mengembangkan Kompetensinya dalam Pengajaran Matematika untuk Meningkatkan CBSA. Tarsito.

[17] Ruseffendi, E.T. (1991). Penilaian Pendidikan dan Hasil Belajar Siswa Khususnya dalam Pengajaran Matematika untuk Guru dan Calon Guru. Diktat.

[18] Ruspiani. (2000). Kemampuan Siswa dalam Melakukan Koneksi Matematika. Tesis, Universitas Pendidikan Indonesia.

[19] Subino. (1987). Konstruksi dan Analisis Tes. Dirjen Dikti Depdikbud.

[20] Slavin, R.E., \& Davis, N. (2006). Educational Psychology: Theory and Practice. Allyn and Bacon.

[21] Sudjana, N., \& Arifin, D. (1988). Cara Belajar Siswa Aktif dalam Proses Belajar Mengajar. Penerbit Sinar Baru.

[22] Suherman, E., \& Winataputra, U.S. (1992). Strategi Belajar Mengajar Matematika. Universitas Terbuka.

[23] Yaniawati, P. (2001). Pembelajaran dengan Pendekatan OpenEnded dalam upaya Meningkatkan Kemampuan Koneksi Matematika Siswa. Tesis, Universitas Pendidikan Indonesia.

[24] Joyce, B., \& Weil, M. (1992). Model of Teaching. Allyn and Bacon.

[25] Krulik, S., \& Reys, R.E. (1980). Problem Solving in School Mathematics. NCTM. 